\title{
THE BENEFITS OF CLOUD SERVICES USAGE AS A CONTEMPORARY APPROACH IN THE WINE INDUSTRY
}

\author{
Vladisavljević Radovan $^{1}$
}

Soleša Dragan ${ }^{2}$

\begin{abstract}
The scope of this paper is to present the business model in the wine industry based on cloud solutions. In the modern world of business, speed and availability are crucial; unfortunately, the nature of the wine industry tends to limit the number of business participants. Managing processes in the wine industry is labor intensive so it is difficult to meet the market demand. Through the analysis of case studies and by comparison with other regions in the wine industry, we obtained enough elements for the formulation of our model. The model presented in this paper is oriented towards the domestic wine industry and is in line with current technical and technological capacities. Most of the subjects in the wine industry are located in rural areas of the Republic of Serbia, and has a relatively limited access to certain resources. There is a strong Internet infrastructure in big cities, which is unfortunately not the case with rural regions. The use of modern IT solutions is also a problematic item because participants in the wine industry, despite a solid education, have difficulty recognizing the benefits
\end{abstract}

\footnotetext{
1 Faculty of Economics and Engineering Management in Novi Sad, University Business Academy in Novi Sad, Cvećarska 2, 21000 Novi Sad, Serbia; radovan.vladisavljevic@fimek.edu.rs

2 Faculty of Economics and Engineering Management in Novi Sad, University Business Academy in Novi Sad, Cvećarska 2, 21000 Novi Sad, Serbia; dragan.solesa@fimek.edu.rs
} 
of e-commerce. With this model, the wine industry gets a tool that will make it possible to easily and economically reach customers, new ideas, knowledge and experiences.

Keywords: wine industry / Internet / e-business / e-commerce / cloud solutions / feedback marketing

\section{INTRODUCTION}

Wine production in Serbia has a long tradition and exceptional capacity, but the fragmentation of wineries that have small holdings is an obstacle to better placement. Small wineries, despite the tradition they have, have a restriction in the form of placement of their goods. Wine production is a labor-intensive process that requires time and human labor, so it is difficult to expect winemakers to have a higher market presence. This leads winemakers to be forced to limit their offer to a narrower geographical area in order to be able to take care of their vineyards and wine production.

Through the work, we will show a model that can help winemakers to market their wines without leaving their farms. The combination of modern technologies and the old wine craft can provide the world market with quality wines. Logistics and technology have existed for decades, so it is necessary to organize and technically arrange the existing elements in order to obtain a system that will serve domestic winemakers.

\section{MATERIALS AND METHODS}

Most vineyards are smaller than one hectare. Only a small number of wineries have production on more than 100 hectares. This tells us that winemakers in Serbia are extremely fragmented and we have the most winemakers with a small production volume. This data can be seen in the following table (Republican Bureau of Statistics, 2020). 
Table 1. Number of wine farms and area under vineyards according to the economic size of farm and size of vineyards

\begin{tabular}{|c|c|c|c|c|c|c|c|c|c|c|}
\hline & $\begin{array}{l}\text { त्ञ } \\
\ominus\end{array}$ & 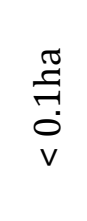 & 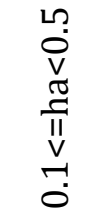 & 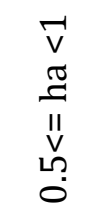 & $\begin{array}{l}\underset{v}{v} \\
\underset{\sigma}{U} \\
\stackrel{\|}{v} \\
\stackrel{-1}{n}\end{array}$ & $\begin{array}{l}\stackrel{L}{v} \\
\stackrel{v}{\sigma} \\
\underset{t}{\|} \\
\stackrel{v}{v} \\
\sim\end{array}$ & 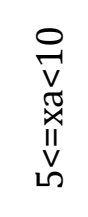 & 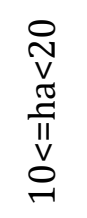 & 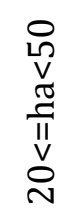 & 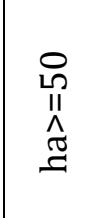 \\
\hline Vineyards & 20466 & 849 & 7367 & 3005 & 1972 & 1657 & 549 & 747 & 692 & 3627 \\
\hline
\end{tabular}

Source: Statistical Office of the Republic of Serbia

This data was created using a survey conducted by the Statistical Office of the Republic of Serbia in 2018. The results are not surprising if we take into account the historical development of agriculture in the Republic of Serbia as well as the lack of incentives for the wine industry in the past.

Agricultural production has a significant impact in the Republic of Serbia, both on the domestic gross product and on the percentage of population employed in this branch of industry. According to a study conducted by the United Nations, we can see the differences between 2008 and 2018.

The number of inhabitants has decreased, as well as all other parameters, and this tells us that agriculture is in contraction, at least according to these data. These data tell us that significant incentives are needed for agriculture to recover. Incentives do not only mean financial subsidies, but also the creation of a system of modernization of agricultural production.

The inherited system under which agriculture operates results in the results shown. However, the presented research emphasizes that the Republic of Serbia has done a lot to create a strong IT infrastructure. This infrastructure can greatly help create a better business environment. This is important information for our work, because the presented model relies on the existence of IT infrastructure. 
Table 2. Basic indicators of agricultural production (ITU-FAO, 2020)

\begin{tabular}{|l|c|c|c|c|}
\hline & 2008 & 2018 & Difference & Diff \% \\
\hline Population & 9060103 & 8802754 & -257349 & -2.84 \\
\hline $\begin{array}{l}\text { Agriculture, value added } \\
\text { (\% of GDP) }\end{array}$ & 7.44 & 6.2 & -1.24 & -16.67 \\
\hline $\begin{array}{l}\text { Agricultural land } \\
\text { (\% of land area) }\end{array}$ & 41.2 & $\begin{array}{c}39.33 \\
(2016)\end{array}$ & -1.87 & -4.54 \\
\hline $\begin{array}{l}\text { Rural population } \\
\text { (\% of total population) }\end{array}$ & 45.45 & 43.91 & -1.54 & -3.39 \\
\hline $\begin{array}{l}\text { Employment in agriculture } \\
\text { (\% of total employment) }\end{array}$ & 25.05 & 17.08 & -7.97 & -31.82 \\
\hline $\begin{array}{l}\text { Employment in agriculture, } \\
\text { female (\% of female } \\
\text { employment) }\end{array}$ & 25.97 & 14.74 & -11.23 & -43.24 \\
\hline
\end{tabular}

Source: Statistical Office of the Republic of Serbia

From the previous table it can be seen that agriculture is the dominant factor of employment. However, this factor as well as other factors show a significant decline. This shows us that domestic agricultural production is insufficiently competitive.

The impact of winery size on business has not yet been fully explored. Numerous studies have been done, such as the study related to the internationalization of wineries in the Italian region of Sicily. According to the research results, the characteristics of successful export-oriented wineries are: 1) a larger physical and economic size, 2) longer experience in international markets, 3) management by highly educated entrepreneurs who are proficient in foreign languages, and 4) implementation of voluntary certification schemes (Galati, et. al., 2017, 2406-2420).

On the other hand, we have research and development issues. This function is crucial, both for the company's survival in the market and for development. New products and technologies can greatly increase a company's competitiveness. Research (Giacomarra, et. al. 2019) on the example of the Italian wine industry shows us that it is important to have good connections at the local level. Large companies can easily invest in human resources, while smaller manufacturers would have to create alliances to mitigate risks. 
Changes in the wine industry in the modern environment are significant and visible in every sphere of business. The traditional way of business of winemakers was based on the transfer of knowledge from older to younger generations. However, research done in New Zealand shows that knowledge transfers no longer go in one direction. New generations, thanks to their education and / or work experience, can contribute to the family business (Woodfielda, Hustedb, 2017, 5769).

Although this research was done on the example of the foreign wine industry and as such cannot be fully applied to our climate, the results of the research still give us a good insight into the size and strength of the wine market. With the development of the Far East, especially China, new challenges appear, both in the form of new markets and in the form of new competitors.

Market analysis has shown that the Chinese market is dominated by oligopolies that are geographically linked to famous and well-known regions where quality grape varieties are grown (Zheng, Wang, 2016, 113). Wine production and grape growing are closely linked to keep costs to a minimum, and the division of the Chinese market is well defined. There are a number of barriers to entry and new competitors can be easily identified. Low-to-middle-end consumers are best divided, but high-end markets still have room for development. In other words, foreign quality wines have an open Chinese market.

All that has been said so far only gives us the idea of the potentials of the wine market. In the Republic of Serbia, the wine industry has a lot of difficulties, and the quality of wine varies depending on the region and the year of harvest. Small winemakers can hardly access domestic markets, and it is difficult to think about foreign centers at this time. The use of information and communication technologies (ICT) can to some extent help winemakers access the market more easily.

The use of ICT in the wine industry is not a new idea, however foreign producers have different problems. The difference between foreign and domestic wine producers is that foreign producers have a problem preserving the brand, and domestic ones usually have a problem entering the market. 
A good example of this claim is the SMARTVINO project which is part of an Italian project funded by Tuscany (Del Mastio, et. al., 2016, 142-149). The aim of the project is to promote a software platform through which customers will be able to access wine data with their mobile phones. The purpose of this is to establish a strong brand based on geographical origin. Namely, through the software, customers can see how the specific bottle of wine they own came to them.

In addition to statistics and historical data on a particular wine and producer, the software also offers a number of options such as pairing dishes with the appropriate wine. This is a classic example of how one group develops the market through brand education and promotion. When we talk about a brand, we do not mean only the type of producer or a specific wine, but also the brand of Italian wines.

The three, we can freely say, superpowers in wine production on European soil are France, Italy and Spain. These three countries compete not only for customers but also for the prestigious position of the best wine producer. Centuries of experience with the help of high technology is the way in which European manufacturers are trying to establish market dominance.

The use of social networks and data analysis techniques such as big data give wine producers a clear picture of consumers and consumer habits (Sottini, et. al., 2019, 127-140). Big data is a relatively new system that relies on large databases and advanced algorithms that are able to find trends and patterns in data. By analyzing the content that can be found on the social network Flickr, and related to the Chianti Classico region, the researchers obtained extremely high-quality data on wine consumers.

Modern technologies offer geopositioning as well as inserting tags into photos that users post on social networks. In this way, the researchers were able to determine exactly when the photograph was taken. In addition, by crossing the image data with descriptions and posts on some other social networks, even more detailed information can be obtained.

Cloud solutions are a relatively new concept and new applications of this solution appear every day. The term itself refers to a set of technologies that are intertwined so that we have network capacity, computer and software resources available to customers (Chopra, 2018, 1). The goal of the cloud solution is to create a system of services that will be provided 
over the Internet. These services can be in the domain of renting processing power, memory capacities, etc.

Over the years, cloud services have crystallized and today we have: SaaS Software-as-a-Service, AaaS - Application-as-a-Service, PaaS - Platformas-a-Service, IaaS - Infrastructure-as-a-Service and HaaS - Hardware-asa-Service. All the mentioned models of cloud systems are still in development and new models can be expected in the future. The purpose of the cloud is to provide cheap and scalable solutions to a market that increasingly relies on digital technologies.

Thanks to the popularity of cloud solutions (regardless of the model), a cheap and accessible Internet of Things (IoT) system is increasingly possible. The cost of data transmission over the network will increasingly be a minor problem, both economically and technically, but the mode of transmission and heterogeneity of devices will be an increasing challenge (Al-Turjman, 2020, 158). All this tells us that today we have a large selection of different technologies. Thanks to cloud solutions, wine producers do not have to create their own solutions, but can implement a cloud in a quick and easy way..

What is important to note is that cloud solutions can be easily adapted to the business, as the business expands, so additional resources can be purchased. The use of specialized software or hardware tools can now be much more easily regulated in terms of cost and ownership. All tools used via the cloud are owned by the service provider, so everything is related to security, software versions, etc... care of the one who provides services through the cloud. On the other hand, data together with output values (outputs - reports, etc.) are owned by the user.

In this way, users get a lot of value for relatively small investments. In the previous part of the text, we mentioned the appearance of IoT. For now, no major impact of this set of technologies is expected, but in the near future this will be a significant source of information. IoTs are essentially devices that are able to connect to the Internet to use some resources. These devices are able to send and receive data, thus being able to communicate with various services. This will lead to the fact that in the future, not only people but also machines or software related to a device will appear as clients. 
For example, ordering wine will be done by customers but also devices (such as refrigerators) that are equipped with the necessary hardware and software. All this tells us that the future of the wine industry, at least as far as cloud solutions are concerned, will lie in the data. Data will become extremely important and in order to get as much data as possible, it will be necessary to use a business intelligence (BI) system and data storage (DW).

Snowflake is the first DW system designed to be used via a cloud, so this service can be considered as a "data warehouse as a service" (Anoshin, Shirokov, Strok, 2020, 14). DWs are systems that store a large amount of data, which are not operational databases but a set of data that is archived. Using various software tools, the data is extracted from the DW and further processed.

International experience already shows that small and medium enterprises are aware that DW systems exist and that these systems bring them certain benefits (Tutunea, 2020, 37). On the other hand, business intelligence can be seen as a set of analytical systems through which decision makers can more easily formulate their decision. In essence, these are analytical systems that have emerged in response to market demands for better and higher quality tools. Business intelligence is still evolving and it can be expected that the development of artificial intelligence will largely reflect on the further course of development.

\section{RESULTS}

In light of all that has been said so far, domestic winemakers can hardly enter the market without the help of modern technology. The difficult legacy that affects the development of the wine industry relates primarily to the fragmentation of holdings leading to small capacities. Industrial production requires capacities to meet larger markets. This is a big problem that will be a big obstacle for domestic winemakers in the near future to enter large markets.

On the other hand, small wineries have a well-developed production system and they are dedicated to quality. The recipes of some wines such as bermet are passed down from generation to generation, which is important to note, because this technology can be difficult to maintain in 
an industrial environment. In other words, local winemakers work at the craft level, where we have a commitment to high quality.

Figure 1. Model of usage of cloud solutions in the business of wineries

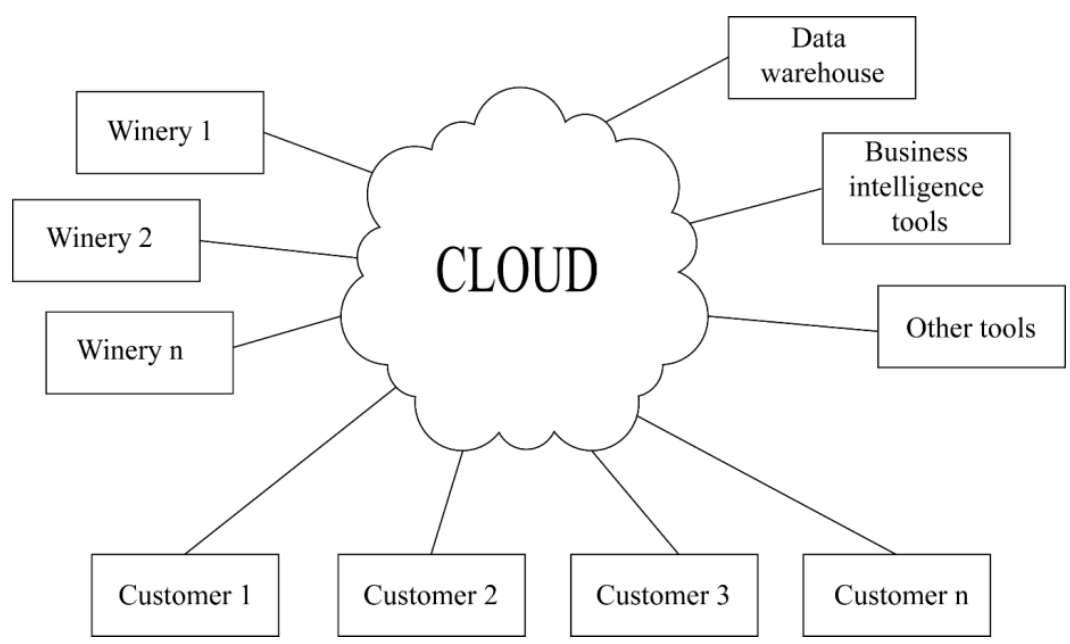

Source: Author's

The artisanal way of production has the characteristic that it is somewhat better and often the customers themselves have an influence on the creation of products and services. This is perhaps the best characteristic of domestic winemakers is the high quality that they could adapt to the needs of individual consumers in the future. At the heart of the model presented is information and data obtained from the market. The market is the best arbiter of newly created value, so data and information from the market are valuable.

Without data and information from the market, it is practically impossible to imagine business analytics. The results of business analysis are important for further processing with business intelligence tools, in other words the whole system of decision making through business intelligence is based on information systems of companies. In other words, the better and more organized the way data is collected, stored and processed, the more effective business intelligence is. It is hard to imagine that with the current business system of a domestic winery, business intelligence will benefit. 
The way of survival of domestic winemakers can be in the search for market niches or a change in business strategy that will strive to enlarge wineries. However, regardless of the strategy, information systems must exist in order to meet the market demands. In earlier periods, the implementation of information systems was a challenging task due to its complexity and diversity in protocols.

Modern cloud-based information systems have the property of relying on Internet technologies to reduce implementation time and complexity. The Internet uses a relatively small number of data transmission protocols so that different products are conditioned to work in accordance with the set parameters. Which leads us to the fact that different software products can work together, in other words, what is the output to one software is the input to another.

On the other hand, cloud solutions are relatively simple for users, not only during the implementation but also during the exploitation of the information system. Simple interfaces, customer support and the like can greatly help users make the best use of their information systems.

Through the paper, we also emphasized that domestic winemakers are often limited by the fund of knowledge related to the use of sophisticated information systems. However, many of the solutions on the market are specifically designed so that users can easily navigate. With the spread of the Internet and mobile technologies, more and more people are using advanced software and there are fewer and fewer barriers that prevent users from using new technologies.

Mobile technologies are a special issue that is important for the presented model, with the most important representative of mobile technologies being the mobile phone. Mobile phones have become hightech mini-computers, which integrate other technologies such as cameras and global positioning systems. Today, it is not possible to ignore mobile technologies and many customers access various contents with mobile technologies and make purchases through them.

The presented model provides a much-needed compromise between the artisanal approach to production and industrial market presence. Winemakers can present and sell their wines online, and customers can quickly and easily compare prices and features. An additional advantage for winemakers is that they can handle a large amount of data and thus 
improve their offer. With the development of the market, they can become highly competitive with large foreign producers. This applies to certain market niches, but it is also a good start for the domestic wine industry in a global environment.

Future researchers are now left with a task to improve the model with elements of additional feedback with which winemakers could customize their wines. Wines can be enriched by adding different spices or creating mixtures of different types of wine. In this way, users themselves could create unique flavors. Today, we live in an era in which even large industrial complexes can create highly customized products, so even small producers will have to follow this trend.

Domestic winemakers will hardly be able to compete with foreign producers, especially from countries that are considered superpowers in the wine industry. Countries like France, Italy and Spain have an extremely developed wine industry, in which winemaking is a matter of prestige. The only way for domestic winemakers to survive in the market is to accept good business practice and focus entirely on market satisfaction.

This is not an easy task because every business entity has the same goal, regardless of the industry in which it is located. The key to markets is in the quality processing of information. Only in this way can valid conclusions be reached. Traditional ways of collecting information, which is based on historical data, is no longer enough. Historical data may be interesting to some extent, but markets are changing and evolving so rapidly that the only valid data are those produced in the recent past.

\section{LITERATURE}

1. Broj gazdinstava i površina pod vinogradima prema ekonomskoj veličini gazdinstva i veličini vinograda. (2020). Republički zavod za statistiku, pristupljeno (30.11.2020.), url:

https://data.stat.gov.rs/Home/Result/1300020206?languageCode $=$ sr-Cyrl

2. International Telecommunication Union (ITU) and Food and Agriculture Organization of the United Nations (FAO). (2020). 
Status of Digital Agriculture in 18 countries of Europe and Central Asia.

3. Galati, A., Crescimanno, M., Tinervia, S., Iliopoulos, C., Theodorakopoulou, I. (2017). Internal resources as tools to increase the global competition: the Italian wine industry case, British Food Journal, Volume 119 Issue 11, pp. 2406-2420.

4. Giacomarra, M., Shams, M., S., S., Crescimanno, M., Sakka, G., Gregori, L., G., Galati, A. (2019). Internal vs. external R\&D teams: Evidences from the Italian wine industry, Journal of Business Research.

5. Woodfielda, P., Hustedb, K. (2017). Intergenerational knowledge sharing in family firms: Case-based evidence from the New Zealand wine industry, Journal of Family Business Strategy, Volume 8, Issue 1, pp.57-69.

6. Zheng, Q., Wang, H., H. (2016). Market Power in the Chinese Wine Industry, Agribusiness, Vol. 00 (0), pp. 1-13.

7. Del Mastio, A., Caldelli, R., Casini, M., Manetti, M. (2016). SMARTVINO project: When wine can benefit from ICT, Wine Economics and Policy, Volume 5, Issue 2 pp. 142-149.

8. Sottini, A., V., Barbierato, E., Bernetti, I., Capecchi, I., Fabbrizzi, S., Menghini, S. (2019). Winescape perception and big data analysis: An assessment through social media photographs in the Chianti Classico region, Wine Economics and Policy, Volume 8, Issue 2, pp. 127-140.

9. Chopra, R. (2018). Cloud Computing. Mercury Learning and Information, Dulles, Virginia, pp. 1.

10. Al-Turjman, F. (2020). The Cloud in IoT-enabled Spaces. CRC Press, pp. 158

11. Anoshin, D., Shirokov, D., Strok, D. (2020). Jumpstart Snowflake: A Step-by-Step Guide to Modern Cloud Analytics. Apress, pp. 14.

12. Tutunea, M. (2020). Data Management Software Solution for Business Sustainability - An Overview in Business Intelligence and Analytics in Small and Medium Enterprises (Eds. Melo, N., P., Marchado, C.), CRC Press. pp. 34 


\title{
BENEFITI UPOTREBE SISTEMA OBLAKA KAO SAVREMENI PRISTUP U VINSKOJ INDUSTRIJ
}

\author{
Vladisavljević Radovan
}

\author{
Soleša Dragan
}

Sažetak: Cilj ovog rada je predstavljanje poslovnog modela $u$ vinarskoj industriji zasnovanog na sistemu Oblaka. U savremenom poslovnom svetu brzina i dostupnost su presudni; nažalost, priroda vinske industrije teži da ograniči učesnike $u$ poslu. Upravljanje procesima u vinarskoj industriji radno je intenzivno, pa je teško zadovoljiti potražnju. Analizom studija slučaja i upoređivanjem sa drugim regionima vinske industrije, dobijamo dovoljno elemenata za formulaciju našeg modela. Model predstavljen u ovom radu orijentisan je na domaću vinsku industriju $i$ u skladu je sa trenutnim tehničkim $i$ tehnološkim kapacitetima. Većina subjekata u vinskoj industriji nalazi se u ruralnim područjima Republike Srbije i ima relativno ograničen pristup određenim resursima. U velikim gradovima postoji jaka Internet infrastruktura, što nažalost nije slučaj sa ruralnim regionima. Upotreba savremenih IT rešenja takođe je problematična stavka, jer učesnici u vinskoj industriji, uprkos solidnom obrazovanju, imaju poteškoće u prepoznavanju benefita e-trgovine. Ovim modelom vinska industrija dobija alat koji će lako i ekonomično doći do kupaca, novih ideja, znanja $i$ iskustava.

Ključne reči: vinarska industrija, Internet, e-poslovanje, etrgovina, rešenja sistema Oblaka, marketinška povratna sprega. 